\title{
Induction of Resistance against Sorghum Downy Mildew by Seed Treatment with Duranta repens Extracts
}

\author{
Manjunatha H.P a1, Heminder Singha2, Jyoti Bala Chauhanb1, Farhan Zameerb2 \\ and Rajkumar H. Garampallia* \\ ${ }^{a}$ Department of Studies in Botany, University of Mysore, Manasagangotri, Mysore - 570 006, India.

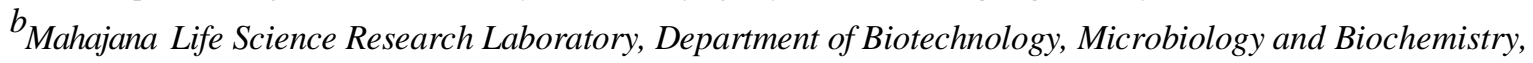 \\ Mahajana Research Foundation, Pooja Bhagavat Memorial Mahajana Post Graduate Centre, Mysore - 570 \\ 016, India.
}

\begin{abstract}
Induction of resistance against plant diseases by seed treatment is simple, cost effective and an efficient strategy for disease management. Aqueous extracts of three plants namely, Duranta repens, Polyalthia longifolia and Parthenium hysterophorus were evaluated for induction of resistance against sorghum downy mildew at $2.5 \%$ and $5 \%$ concentrations by seed dip method. Seeds were dipped for $3 \mathrm{~h}$, followed by decanting and incubation to obtain sprouts. The sprouts obtained after $42 \mathrm{~h}$ incubation were inoculated by dipping in conidial suspension, planted in pots and raised in greenhouse conditions to observe systemic disease incidence. Duranta repens extract at $2.5 \%$ and $5 \%$ concentrations provided protection of $50.9 \%$ and $85 \%$ respectively, as against $38.5 \%$ protection provided by positive control. Biochemical analysis showed enhanced levels of defence enzymes PAL and POX in plant extract-treated seedlings. Evaluation of 6 solvent fractions of D. repens revealed disease protection by almost all fractions, indicating synergistic effect by various biochemicals. The method is helpful to attain goal of sustainable agriculture with biological and ecological safety. The novel method developed in the present investigation of using weight of seedlings as indicator of health index is effective and more convenient as compared to measurement of root and shoot lengths.
\end{abstract}

Key words: Downy mildew, Duranta repens, Induction, Organic farming, Sorghum, IAH consortium.

\section{Introduction}

Sorghum (Sorghum bicolor (L.) Moench) is an agronomically important cereal crop, which stands fifth only after Maize, Wheat, Rice and Barley in terms of world-wide production [1]. According to All India Coordinated Sorghum Improvement Project (AICSIP) 2005-06 report, downy mildew of sorghum caused by Peronosclerospora sorghi (W. Weston and Uppal) C.G. Shaw, caused significant damage in South India, especially South Karnataka province. It was found predominant in all the districts surveyed in Karnataka, both on grain sorghum and fodder sorghum [2]. Methods currently employed for management of downy mildew disease of sorghum are seed dressing by systemic fungicide Metalaxyl 35\% WS, spray of contact fungicides like Mancozeb 75\% WP and use of resistant hybrid varieties [3]. Use of chemicals is discouraged in organic farming. Utilization of resistant hybrid varieties against downy mildew is an environment friendly method but perfectly resistant varieties are either not available or not durable due to development of new virulent strains of pathogen $[4 ; 5]$. Tolerant varieties act as reservoir of pathogen, besides, the method is costly, requires huge investment and technical knowledge which confines the resistant variety development to research institutions, making the farmers dependent. Hence in the present investigation, an effort was made to manage the disease by environment friendly and economical methods.

Since resistance in plants is highly versatile and elastic, even the susceptible plant can be protected from the disease by the developing systems to induce and enhance the plants own defence mechanisms [6]. The induction of systemic acquired resistance results in the development of a long lasting, broad spectrum immunity in non- infected tissues against a broad range of plant pathogens including viruses, bacteria and fungi $[7 ; 8 ; 9]$. There are many reports on various types of induced resistance in a variety of host-pathogen systems using biotic or abiotic agents $[10 ; 11]$.

The interaction between the pathogen and host plant induces some changes in cell metabolism, primarily in the enzyme activities, including that of phenylalanine ammonia lyase (PAL), peroxidase (POX), polyphenol oxidase (PPO), lipoxygenase (LOX), superoxide dismutase (SOD) and1,3 glucanase $[12 ; 13 ; 14 ; 15$; 16]. Activation of local responses at the site of infection can be followed by establishment of secondary immunity throughout the plant, termed as induced systemic resistance, which is long lasting and effective against a broad spectrum of pathogens [17]. Induced resistance is the induction of plants defence mechanism, triggered by avirulent or virulent pathogens, or chemical inducers such as salicylic acid (SA), 2,6-dichloroiso- 
nicotinic acid (INA) and benzo (1,2,3)-thiadiazole-7- carbothionic acid-s-methyl ester (BTH). Several studies have demonstrated the operation of ISR in various crop plants against a range of pathogens possessing different infection strategies [18; 19; 7].

Phenylalanine ammonia lyase (PAL) is one of the biochemical markers of induced resistance. It is considered to be the principal enzyme of the phenylpropanoid pathway, which is the prime intermediary in the biosynthesis of phenolics and flavonoids [20]. The presence of phenolic compounds in plants and their synthesis in response to infection is associated with disease resistance.

The induction of peroxidase (POX) activity in plants occurs in response to numerous biotic and abiotic stimuli, including exposure to pathogens or elicitor preparations, chemical oxidizing agents, red light, and mechanical stimuli $[12 ; 21 ; 22]$. POX is believed to play roles in auxin catabolism, the oxidation of phenolics to form lignin, the cross-linking of hydroxyproline-rich glycoproteins in plant cell walls, and the production and breakdown of hydrogen peroxide and other reactive oxygen species [23; 24]. The roles that POX can play in cell wall toughening and in the production of toxic secondary metabolites and its simultaneous oxidant and anti-oxidant capabilities can make it an important factor in the integrated defence response of plants to a variety of stresses $[12 ; 21]$.

One of the more intensively studied components of induction is salicylic acid. In tobacco, application of exogenous salicylic acid induces the PR gene expression and partial resistance to pathogen such as TMV [25]. There are several reports indicating the resistance inducing activity of plant extract as well as components of plant extracts $[26 ; 27 ; 28 ; 29 ; 30 ; 31 ; 32]$. Natural products like plant extracts are preferred over chemicals as an inducer of resistance. Therefore, the current study focuses on the preventive approach of this important crop disease by environment friendly, cost-effective methods.

\section{Materials And Methods}

\subsection{Preparation of plant extracts}

Fresh biomass of three botanicals was collected and weighed $16 \mathrm{~g}$ each (TABLE 1). Plant material (16 g) of Duranta repens, Polyalthia longifolia and Parthenium hysterophorus was crushed in mortar and pestle in 40 $\mathrm{mL}$ of distilled water. The crushed biomass was poured into culture tubes and kept over-night for exudation of biochemicals. Later, the solution was filtered through muslin cloth, followed by Whatmann No.1 filter paper. The filtered plant extracts which served as $40 \%$ stock solutions, were stored at $5{ }^{\circ} \mathrm{C}$ in refrigerator and were diluted by addition of distilled water according to requirements.

\subsection{Preparation of pathogen inoculum}

The initial conidial inoculum was obtained from systemically infected, uniformly sporulating leaves of sorghum, collected from downy mildew infected sorghum plants at Bogadi, Mysore, Karnataka, India. The inoculum was multiplied by sprout dip methods [33] and maintained on downy mildew susceptible sorghum cultivar DMS-652 (seeds obtained from University of agricultural sciences, Dharwad, Karnataka state, India) at Botanical garden, Department of studies in Botany, University of Mysore, India. Conidial inoculum of pathogen was obtained by following paper-towel technique [34]. Tween-20 was added at the rate of one drop per litre. A sample of $5 \mathrm{~mL}$ was drawn and subjected to haemocytometer count. The final volume was adjusted by addition of distilled water to obtain conidial concentration of $6 \times 10^{5}$ spores $/ \mathrm{mL}$.

\subsection{Green house evaluation of plant extract for induction of resistance}

Green house evaluation of plant extract for induction of resistance was done according to IAH Consortium technique [35]. Three plant extracts at $2.5 \%$ and $5 \%$ concentrations were used for giving seed dip treatment to 100 sorghum seed each in plastic cups. Negative control comprised distilled water treatment and positive control comprised $2 \mathrm{mM}$ salicylic acid treatment. The solutions were decanted $3 \mathrm{~h}$ later. The cups were covered with petri plate lids and incubated at room temperature for $42 \mathrm{~h}$ to obtain seedlings. The seedlings in each cup were inoculated by $5 \mathrm{~mL}$ of conidial suspension, early morning before $6 \mathrm{AM}$. The suspension was decanted carefully to the last drop after $5 \mathrm{~min}$. The seedlings were uniformly spread at the bottom of each cup, covered with petri plate and incubated for $24 \mathrm{~h}$ at room temperature. The seedlings from each cup representing each treatment were divided and sown in 4 pots of $15 \mathrm{~cm}$ diameter. Disease incidence in the form of systemic infection was recorded for all the pots twice a day for 15 days $[36 ; 35]$. Besides the controls, the treatments showing significant disease suppression as compared to negative control were selected for measurement of plant growth parameter. Plants along with root system were removed from each pot, packed in paper bags, placed in hot air oven at $72{ }^{\circ} \mathrm{C}$ for $48 \mathrm{~h}$ and weighed to obtain dry biomass yield per pot. Experiment was repeated once with similar results and mean of the readings was taken for calculations. Disease protection provided by the treatments was calculated according to equation (1). 


\subsection{Effect of plant extracts on seed germination and seedling vigour}

DMS-652 seeds were put in plastic cups of $5 \mathrm{~cm}$ diameter with filter paper lined bottom, at the rate of 100 seeds/cup. The experiment comprised $2.5 \%$ D. repens extract treatment and 2 controls. (D. repens $5 \%$ extract treatment was not included for seedling vigour experiment in spite of high percentage disease protection shown in green house experiment due to distinctly poor growth obtained). The entire experiment was conducted with 4 replicates. Stock solution of the plant extract was diluted by addition of distilled water to obtain $2.5 \%$ solution. Aqueous extract of the botanical at $2.5 \%$ concentration was used for seed dip treatment (3 h) in plastic cups. Seeds treated with distilled water served as negative control and seeds treated with $2 \mathrm{mM}$ salicylic acid solution served as positive control. Germination test was carried out by the paper towel method [37]. Fifty treated seeds were placed on each of moist germination paper equidistantly. Another pre-soaked towel was placed on the first one so that the seeds were held in position. The towel were then rolled and wrapped with polythene to prevent drying and incubated at $25 \pm 2{ }^{\circ} \mathrm{C}$ with one end of paper- roll dipping in water. After seven days, the towels were unrolled. Seedling vigour was analyzed according to Abdul Baki and Anderson (1973) [38], and compared to an alternative variant method termed as Health index (as described ahead). Four sets of 100 seeds each were maintained for all different treatments. The seedlings obtained from each replicate were measured for shoot and root length, thereafter collected, bundled and weighed on balance. The percentage of germination and seedlings weight was recorded. Experiment was repeated once with similar results and mean of the readings was taken for calculations. Vigour index and Health index were calculated according to equations (2), (3), (4).

\subsection{Biochemical studies}

To confirm the mechanism of action of disease protection, the treated seedlings were subjected to biochemical tests to assess the levels of defence enzymes in the tissues.

\subsubsection{Phenylalanine ammonia lyase (PAL) assay}

DMS-652 seeds were put in 6 plastic cups of $5 \mathrm{~cm}$ diameter with filter paper lined bottom, at the rate of 100 seeds/ cup. The 6 treatments included 2.5\% D. repens extract treatment (inoculated), 2.5\% D. repens extract treatment (un-inoculated), distilled water treatment (inoculated), distilled water treatment (uninoculated), $2 \mathrm{mM}$ salicylic acid treatment (inoculated), $2 \mathrm{mM}$ salicylic acid treatment (un-inoculated). Seeds were dipped in respective solutions for $3 \mathrm{~h}$, followed by decanting and incubation in moist conditions at room temperature. The treatments requiring inoculation were inoculated after $42 \mathrm{~h}$ of incubation by conidial suspension, in the morning before $6 \mathrm{AM}$. Inoculated and un-inoculated treatments were further incubated for $4 \mathrm{~h}$. Seedlings were harvested after $4 \mathrm{~h}$ of inoculation for PAL enzyme assay. Seedlings $(1 \mathrm{~g})$ were homogenized in $1 \mathrm{~mL}$ of ice cold $25 \mathrm{mM}$ Tris buffer ( $\mathrm{pH} \mathrm{8.8)} \mathrm{in} \mathrm{a} \mathrm{pre-chilled} \mathrm{mortar} \mathrm{and} \mathrm{pestle} \mathrm{on} \mathrm{ice} \mathrm{and} \mathrm{the} \mathrm{homogenate} \mathrm{was}$ centrifuged at $10,000 \mathrm{rpm}$ for $30 \mathrm{~min}$ at $4{ }^{\circ} \mathrm{C}$. The supernatant was collected and used as enzyme source. PAL activity was determined as the rate of conversion of L-phenylalanine to trans-cinnamic acid at $290 \mathrm{~nm}$ as described by Dickerson et al., 1984 [39]. The reaction mixture $(3 \mathrm{~mL})$ consisted of $0.3 \mathrm{~mL}$ of enzyme extract, 1.5 $\mathrm{mL}$ of substrate buffer $(50 \mathrm{mM}$ of L-phenylalanine) and $1.2 \mathrm{~mL}$ of $25 \mathrm{mM}$ Tris- $\mathrm{HCl}, \mathrm{pH} 8.8$. The reaction mixture was mixed well and incubated at $40{ }^{\circ} \mathrm{C}$ for $2 \mathrm{~h}$. The $0.18 \mathrm{~mL}$ of $5 \mathrm{~N} \mathrm{HCl}$ was added to the reaction mixture and vortexed and optical density (OD) was read at $290 \mathrm{~nm}$. The amount of trans-cinnamic acid synthesized was calculated using its extinction coefficient at $9630 \mathrm{~m}^{-1}$ [39]. Blank containing $1.5 \mathrm{~mL}$ of substrate buffer $+1.2 \mathrm{~mL}$ of $25 \mathrm{mM}$ of Tris- $\mathrm{HCl}(\mathrm{pH} 8.8)$ and $0.3 \mathrm{~mL}$ of enzyme were added after the addition of $0.180 \mathrm{~mL}$ of $5 \mathrm{~N} \mathrm{HCl}$. The total activity and specific activity was calculated using the following formula, and the enzyme activity was expressed in terms of $\mu \mathrm{mol}$ of TCA $\mathrm{mg}$ protein/h. Experiments were conducted in three replicates and repeated thrice. Total activity and specific activity calculated according to equations (5), (6), (7).

\subsubsection{Estimation of Peroxidase (POX) activity}

One gram seedlings were harvested after 8 hours of inoculation from respective treatment cups and subjected to POX enzyme assay. Seedlings were homogenized in one $\mathrm{ml}$ of $10 \mathrm{mM}$ phosphate buffer (pH 6.0) in a pre-chilled mortar and pestle on ice. The homogenate was centrifuged at $12,000 \mathrm{rpm}$ for $20 \mathrm{~min}$ at $4{ }^{\circ} \mathrm{C}$ and the supernatant served as enzyme source. Peroxidase enzyme assay was carried out as described by Hammerschmidt et al., (1982) [12], with minor modifications. The reaction mixture (3 mL) consisted of $0.25 \%$ $(\mathrm{v} / \mathrm{v})$ guaiacol in $10 \mathrm{mM}$ potassium phosphate buffer ( $\mathrm{pH}$ 6.0) containing $10 \mathrm{mM}$ hydrogen peroxide. Addition of $100 \mu \mathrm{L}$ of crude enzyme extract initiated the reaction, which was measured spectrophotometrically at 470 $\mathrm{nm}$ for $1 \mathrm{~min}$. One unit of POX enzyme activity is defined as change in absorbance $\mathrm{min}^{-1} \mathrm{mg}^{-1}$ protein. Experiments were conducted in three replicates and repeated thrice. 


\subsubsection{Protein Estimation - Lowry's method}

To calculate the specific activity of enzymes, the protein content in the crude extracts was estimated by following the standard procedure of Lowry's method (1951) [40], using BSA (Sigma) as the standard. Experiments were conducted in three replicates and repeated twice

\subsection{Evaluation of solvent extracts for induction of resistance.}

Biomass of the selected plant were shade dried, powdered, filtered through a mesh of $1 \mathrm{~mm}$ size. Twenty five grams of the powder was filled in the thimble and extracted successively with hexane, chloroform, diethyl ether, acetone, ethanol and distilled water for 15-20 cycles each. All the extracts were concentrated using rotary flash evaporator and preserved at $5{ }^{\circ} \mathrm{C}$ in glass vials until further use.

Two $\mathrm{mg}$ of each of the dried, evaporated solvent extract of $D$. repens was dissolved in $200 \mu \mathrm{L}$ of methanol and then the volume made upto $5 \mathrm{~mL}$ by addition of distilled water. Thus obtained $5 \mathrm{~mL}$ of each diluted solvent extract was used for giving seed dip treatment to 100 sorghum seeds in plastic cups. Negative control comprised $200 \mu \mathrm{L}$ methanol $+4.8 \mathrm{~mL}$ distilled water treatment and positive control comprised $5 \mathrm{~mL}$ of $2 \mathrm{mM}$ salicylic acid treatment. The solutions were decanted $3 \mathrm{~h}$ later. The cups were covered with petri plate lids and incubated at room temperature for $48 \mathrm{~h}$ to obtain seedlings. The seedlings in each cup were inoculated by $5 \mathrm{~mL}$ of conidial suspension early morning before $6 \mathrm{AM}$ as described earlier. The seedlings from each cup representing each treatment were divided and planted in 4 pots of $15 \mathrm{~cm}$ diameter. Disease incidence in the form of systemic infection was recorded. Experiment was repeated once with similar results and mean of the readings was taken for calculations.

\subsection{Statistical analysis}

Data was subjected to one way analysis of variance (ANOVA), followed by Tukey's post test at $\mathrm{P} \leq 0.05$ level of significance using Graphpad prism 5 software.

\section{Results}

\subsection{Efficacy of aqueous plant extracts for induction of resistance under green house condition.}

The seedling raised from the sorghum seeds treated with $2.5 \%$ and $5 \%$ of $D$. repens extract showed the $50.9 \%$ and $85 \%$ protection respectively against downy mildew disease, as compared to $38.5 \%$ protection provided by positive control. Among all the treatments, disease protection was found maximum in the $D$. repens $5 \%$ plant extract treatment (TABLE 2).

\subsection{Effect of seed treatment with inducers on seed germination and vigour index}

Results of the study clearly indicated that seed germination and vigour index of sorghum seedling could be enhanced by seed treatment with plant extract. Vigour index ranking of the treatments were found to corelate well with the health index rankings. Among the treatments, $2.5 \%$ D. repens extract showed highest vigour index of 904 and health index of 296.1 (TABLE 3).

\subsection{Biochemical studies}

Two defence related enzymes, peroxidase and phenylalanine ammonia lyase showed higher activity in plant extract treated seedlings compared with water treated seedlings (POX assay 8 hours after inoculation and PAL assay $4 \mathrm{~h}$ after inoculation).

\subsubsection{Estimation of phenylalanine ammonia-lyase (PAL) enzyme activity}

$D$. repens extract treatment resulted in a significant increase of PAL activity compared to uninoculated salicylic acid and water treated seedlings. PAL activity of inoculated D. repens $5 \%$ extract treated plants showed the maximum (35.3 $\mu$ mole trans- cinnamic acid $\mathrm{mg}^{-1}$ protein $\mathrm{h}^{-1}$ ) enzyme activity. Uninoculated $D$. repens $5 \%$ extract treated seedlings showed the enzyme activity of $26.1 \mu$ mole transcinnamic acid $\mathrm{mg}^{-1}$ protein $\mathrm{h}^{-1}$ (Fig. 1).

\subsubsection{Estimation of Peroxidase (POX) enzyme activity.}

Spectroscopic analysis showed D. repens plant extract treatment caused significant increase of POX activity in host 8 hours after inoculation and in un-inoculated seedlings, compared to water treated and salicylic acid treated seedlings. Uninoculated $D$. repens extract treated plants resulted in significantly higher enzyme activity than the un-inoculated salicylic acid and water treated seedlings. POX activity of inoculated D. repens extract treated plants showed higher activity than un-inoculated D. repens extract treated plants. The POX activity did not significantly change in water treated plants during the experimental time course (Fig. 2). 


\subsection{Evaluation of solvent extracts for induction of resistance.}

Resistance against downy mildew disease was induced by almost all the solvent extracts of $D$. repens, with maximum percent protection of $44 \%$ provided by chloroform extract, as against $32.7 \%$ protection provided by positive control (TABLE 4).

\section{Discussion}

An early recognition of the pathogen followed by immediate initiation of appropriate defence responses is the key to a plants successful defence against invading pathogen. The induction of resistance phenomena can be used as an approach to activate the defence components of the susceptible host cultivar for rapid response upon pathogen challenge, mimicking the incompatible interaction. With concern for the environmental, eco-friendly natural products like plant extracts are preferred over chemicals as inducers of ISR. This study reports the use of $D$. repens plant extract to induce resistance in susceptible sorghum plants against downy mildew disease by seed treatment. D. repens $2.5 \%$ extract treatment did not affect seed germination and seedling vigour index of sorghum but provided protection against pathogen. The novel method developed in the present investigation of using weight of seedlings as indicator of health index is effective, rapid and more convenient as compared to measurement of root and shoot lengths.

The present study assessed the effect of the plant extract seed treatment on sorghum against $P$. sorghi infection. During our initial screening process under green house condition with seeds treated with $2.5 \%$ and $5 \%$ of different plant extracts, D. repens $5 \%$ extract treated plants showed the maximum protection under green house condition. Results were similar to the earlier studies of pearl millet downy mildew with Datura metel aqueous plant extract [29]. The mechanism by which $D$. metel extract acts as an inducer of resistance could be either by its diffusion through the microscopic ruptures caused by imbibitions of seed or by initiation of an interaction on seed germination through diffusion into coleoptiles and radicals of germinating embryos [41].

Induction of resistance has been measured using biochemical markers in the form of induction of defence related enzymes that are activated upon pathogen infection in the present study. We report the involvement of PAL and POX defence enzyme during the host-pathogen interaction in case of sorghum downy mildew. POX plays several important roles in the disease resistance expressed against a number of pathogen and is responsible for the production of reactive oxygen species [16]. Our finding showed that $D$. repens seed treatment increased the activities of peroxidase enzyme in the both the inoculated and un-inoculated seedlings. It was found that increase of the POX defence enzyme concentration in plants correlated the reduction of disease in $D$. repens extract treated plants compared to the water treatment plant.

PAL the first committed enzyme in the phenyl-propanoid and flavonoid pathways is involved in biosynthesis of phytoalexins, lignin and salicylic acid associated disease resistance expression. The pearl millet seeds treated with aqueous plant extract of Viscum album had shown the maximum increase of the defence related enzyme like PAL [42]. In the present study, a significant increase of PAL in D. repens extract treated seedlings inoculated with pathogen was observed. Thus an incompatible environment may be created by $D$. repens extract seed treatment in the susceptible sorghum cultivar. Hence in $D$. repens extract induced protection of sorghum, PAL may be involved in triggering phenyl propaniod pathway resulting in the increase of defence enzyme and disease protection.

\section{Conclusion}

Induction of disease resistance is an alternative and attractive method for plant protection, as it activates the resistance mechanism in plant and is effective against a broad spectrum of plant pathogens. Since plant extract or plant products are able to induce plant immunity against pathogenic microorganism, their use for the development of products which are capable to protect crops has been envisaged. The present research work will be helpful in the management of disease by environment friendly methods. Further knowledge about the induction of defence related proteins and the mechanism involved in D. repens extract mediated protection might allow the development of a novel method for disease protection of crop plants for sustainable agriculture with appropriate biological and ecological safety.

\section{Acknowledgment}

The corresponding author (Dr. Rajkumar H. Garampalli) is thankful to University Grants Commission for financial support to carry out this work. The authors acknowledge Dr. Y. D. Narayana, Principal Scientist (Pathology), All India Co-ordinated Sorghum Improvement Project, U.A.S., Dharwad, Karnataka, India for providing sorghum seeds. We feel thankful to Dr. K.N. Amruthesh (Assistant Professor) and S.N. Lavanya (Research Scholar), Department of studies in Botany, University of Mysore, Karnataka, India for providing laboratory facilities and guidance to carry out biochemical work. 


\section{References}

[1] Food and Agricultural Organization of the United Nations, 2010. FAOSTAT Database, Rome, Italy, Faostat. Available from: http://faostat.fao.org (verified 2013 jan 10).

[2] N. Seetharama, S. Audilakshmi, T.G. Nageshwar Rao, V.R. Bhagawat, S. Ravikumar, Chari Appaji, S.S. Rao, M. Elangovan, V.A. Tonapi, N. Kannababu, B. Dayakar Rao, A. Ratnavathi Reddy, M.S. Raut, Prabhakar and R.P.S. Grewal, Report of AICSIP coordinating team 2005-06. India: Directorate of Sorghum Research, 2006, 78 .

[3] R.G. Kenneth, Downy mildews of graminaceous crops, in D.M. Spencer (Ed.), The downy mildews (London: Academic Press, 1981) 367-394.

[4] I.R. Crute, J.M. Noorwood and D.L. Gordon, Resistance to phenylamine fungicides in lettuce and brassica downy mildew, Proc. of the Bordeaux Mixture centenary Meeting, British Crop Protection Council, Monograph, Bordeaux, France, 1985, 31, 311-314.

[5] T. Isakeit, G. Odvody, R. Jahn and L. Decanini, Peronosclerospora sorghi resistant to metalaxyl treatment of sorghum seed in Texas. Phytopathology, 93, 2003, S39.

[6] A. Garcia-Brugger, O. Lamotte, E. Vandelle, S. Bourque, D. Lecourieux, B. Poinssot, D. Wendehenne and A. Pugin,. Early signaling events induced by elicitors of plant defences. Molecular Plant-Microbe Interactions. 19, 2006, 711-724

[7] G.E. Vallad and R.M. Goodman, Systemic acquired resistance and induced systemic resistance in conventional agriculture. Crop Science, 44, 2004, 1920 - 1934.

[8] D. Walters, D. Walsh, A. Newton and G. Lyon, Induced resistance for plant disease control: maximizing the efficacy of resistance elicitors. Phytopathology, 95, 2005, 1368-1373.

[9] J. Kuc, What's old and what's new in concepts of induced systemic resistance in plants and its application, in T. Tuzun and E. Bent (Eds.), Multigenic and induced systemic resistance in plants (USA: Springer, 2006) 9-20.

[10] M. Oostendorp, W. Kunz, B. Dietrich and T. Staub, Induced disease resistance in plants by chemicals. European Journal of Plant Pathology, 107, 2001, 19-28.

[11] J.P. Agostini, P.M. Bushong and L.W. Timmer, Glasshouse evaluation of products that induce host resistance for control of scab, melanose, and Alternaria brown spot of citrus. Plant Disease, 87, 2003, 69 - 75.

[12] R. Hammerschimidt, E. Nuckles and J. Kuc,. Association of enhanced peroxidase activity with induced systemic resistance of cucumber to Colletotrichum lagenarium. Physiological Plant Pathology, 20, 1982, 73-82.

[13] F. Mauch, B. Mauch-Mani and T. Boller, Antifungal hydrolysis in pea tissue II. Inhibition of fungal growth by combination of chitinase and ß 1,3 glucanase. Plant Physiology, 88, 1988, 936-942.

[14] H. Ohta, K. Shuida, Y.L. Peng, I. Furusawa, J. Shishiyama, S. Aibara and Y. Morita,. A lipoxygenase pathway is activated in rice after infection with the rice blast fungus Magnapoarthe grisea. Plant Physiology, 97, 1991, 94-98.

[15] T. Fukasawa-Akada, S.D. Kung and X.Z. Watson, Phenylalanine ammonia lyase gene structure, expression, and evolution in Nicotiana. Plant Molecular Biology, 30, 1996, 711-722.

[16] P. Wojtaszek, Oxidative burst: an early plant response to pathogen infection, Biochemical Journal, 322, 1997, 681-692.

[17] M.J. Pozo, C. Cordier, E. Dumas-Gaudot, S. Gianinazzi and J.M. Barea, Localized versus systemic effect of arbuscular mycorrhizal fungi on defence responses to Phytophthora infection in tomato plants. Journal of Experimental Botany, 53, 2002, 525534.

[18] L.C. Van Loon and C.M.J. Bakker Pieterse, Systemic resistance induced by rhizosphere bacteria. Annual Review of Phytopathology, 36, 1998, 453.

[19] M. Heil and R.M. Bostock, Induced systemic resistance (ISR) against pathogens in the context of induced plant defences. Annals of Botany, 89, 2002, 503-512.

[20] R. Whetten and R. Sederoff, Lignin biosynthesis, Plant Cell 7, 1995, 1001-1013.

[21] G. DeJaegher, N. Boyer and T. Gaspar, Thigmomorphogenesis in Bryonia dioica: changes in soluble and wall peroxidases, phenylalanine ammonia lyase activity, cellulose, lignin content and monomeric constituents. Plant Growth Regulation, 3, 1985, 133 148.

[22] J.J. Casal, R.A. Mella, C.L. Ballare and S. Maldonado, Phytochrome-mediated effects on extracellular peroxidase activity, lignin content and bending resistance in etiolated Vicia faba epicotyls, Physiological Plantarum, 92, 1994, 555-562.

[23] S.C. Fry, The Growing Plant Cell Wall: Chemical and Metabolic Analysis. (Harlow, U.K., Longman, 1988)

[24] K.L. Klotz and L.M. Lagrimini, Phytohormone control of the tobacco anionic peroxidase promoter. Plant Molecular Biology, 31, 1996, $565-573$

[25] D. Wendehenne, J. Durner, C. Zhixing and D.F. Klessing, Benzothiadiazole an inducer of plant defence inhibits catalase and ascorabate peroxidase. Phytochemistry, 47, 1998, 651-65.

[26] N. Doke and H.B. Chai, Activation of superoxide generation and enhancement of resistance against compliable races of Phytophthora infestans in potato plants treated with digitonin, Physiological Plant Pathology, 27, 1985, 323 - 334.

[27] N.S. Doubrava, R.A. Dean and J. Kuc, Induction of systemic resistance to anthracnose caused by Colletotrichum lagenarium in cucumber by oxalate and extracts from spinach and rhubarb leaves. Physiological and Molecular Plant Pathology, 133, 1988, 69-79.

[28] T. Yamada, T. Hiramoto, R . Tobimatsu, J. Shiraishi and H. Oku, Elicitor like substances present in barley and wheat seeds, Journal of Phytopathology, 128, 1990, 89-98.

[29] S.P. Devaiah, G.H. Mahadevappa and H.S. Shetty, Induction of systemic resistance in pearl millet against downy mildew pathogen by Datura metel extract. Crop Protection, 28, 2009, 783-791

[30] S. Guleria and A. Kumar, Azadirachta indica leaf extract induces resistance in sesame against Alternaria leaf spot disease, Journal of Cell and Molecular Biology, 5, 2006, 81-86.

[31] M. Govindappa, S. Umesha and S. Lokesh, Adathoda vasica leaf extract induces resistance in rice against bacterial leaf blight disease (Xanthomonas oryzae pv. oryzae) International Journal of Plant Physiology and Biochemistry, 3, 2011 , 6-14.

[32] S. Kagale, T. Marimuthu, J. Kagale, B. Thayumanavan and R. Samiyappan, Induction of systemic resistance in rice by leaf extracts of Zizyphus jujube and Ipomoea carnea against Rhizoctonia solani. Plant Signaling and Behaviour, 6, 7, 2011, 919-923.

[33] Y.D. Narayana, L.K. Mughogho and R. Bandyopadhyay,. Evaluation of greenhouse inoculation techniques to screen sorghum for resistance to downy mildew. Euphytica, 86, 1995, 49-53.

[34] H. Singh and R.H. Garampalli, An efficient technique to obtain conidial inoculum of Peronosclerospora sorghi causing downy mildew of sorghum. Archives of Phytopathology and Plant Protection, 46, 2012a, 656 - 662.

[35] H. Singh and R.H. Garampalli, Screening of plant extracts for organic management of downy mildew of sorghum. Archives of Phytopathology and Plant Protection, 45, 2012b, 1732-1740. 
[36] R.A. Frederiksen, Sorghum downy mildew in the United States: overview and outlook, Plant Disease, 64, 1980, 903-908.

[37] ISTA, International rules for seed testing, Seed Science and Technology, 21, 1993, 141-186.

[38] A.A. Abdul Baki and J.P. Anderson, Vigour determination in soybean seed by multiple criteria, Crop Science, 13, 1973, 630 - 633.

[39] D.P. Dickerson, S.F. Pascholati, A.E. Hagerman, L.G. Butler and R.L. Nicholson, Phenylalnine ammonia-lyase and hydroxycinnamte: Coa ligase in maize mesocotyls inoculated with Helminthosporium maydis or Helminthosporium carbonum, Physiological Plant Pathology, 25, 1984, 111- 123.

[40] O.H. Lowry, N.J. Rosebrough, A.L. Farr and R.J. Randall, Protein measurement with the folin phenol reagent, Journal of Biological Chemistry, 193, 1951, $265-275$.

[41] B.D. Jensen, A.O. Latunde-Dada, D. Hudson and J.A. Lucas, Protection of Brassica seedlings against downy mildew and damping-off by seed treatment with CGA 245704, an activator of systemic acquired resistance, Pesticide Science, 52, 1998, 63-69.

[42] Chandrasekhara, S. Niranjan raj, G. Manjunath, S. Deepak and H.S. Shetty, Seed treatment with aqueous extract of Viscum album induces resistance to pearl millet downy mildew pathogen, Journal of Plant Interactions, 32, 2010, 123-142.

\section{Equations:}

$(1):(\%)$ Protection $=(\%)$ Disease in untreated plants $-(\%)$ Disease in plant extracts treated plants $\times 100$

$(\%)$ Disease in untreated plants

(2): Percentage of germination $=$ No. of seed germinated $\times 100$

Total no. of seed plated

(3): Vigour index $=\%$ seed germination $\times$ (mean shoot length + mean root length).

(4): Health index $=\%$ seed germination $\times$ seedlings weight $(\mathrm{g})$.

(5): Total activity $=$ OD X 100

(6): $\lambda=\underline{\text { Total activity }}$

$120(\mathrm{~min})$

(7): Specific activity $=\underline{\lambda \times 1000}$

$\mathrm{mg}$ of protein

Tables

Table 1. Name of the plants and parts used.

\begin{tabular}{|lll|}
\hline SI. NO & \multicolumn{1}{c}{ Plants } & Parts used \\
\hline $\mathbf{1}$ & Duranta repens L. & Leaves and fruits \\
$\mathbf{2}$ & Polyalthia longifolia Hook f. \& Thoms. & Matured leaves \\
$\mathbf{3}$ & Parthenium hysterophorus L. & Leaves and flowers \\
\hline
\end{tabular}

Table 2. Efficacy of seed treatments with aqueous plants extract on induction of resistance against downy mildew of sorghum under the green house condition.

\begin{tabular}{|lccccc|}
\hline $\begin{array}{l}\text { Treatments } \\
\text { pot }( \pm 0.5)\end{array}$ & Mean plants/ & $\begin{array}{l}\% \text { disease } \\
\text { / pot(mg) }\end{array}$ & \% Protection & Mean dry biomass \\
\hline Water (un inoculated) & 18 & 0 & - & $519.5 \pm 59$ \\
\hline Water (inoculated) & 18 & 100 & 0 & 0 \\
\hline Salicylic acid & $2 \mathrm{mM}$ & 14 & $61.4 \pm 4.7$ & $38.53 \pm 4.78 * * *$ & $141 \pm 2.1$ \\
\hline P.longifolia & $2.5 \%$ & 18 & $98.3 \pm 3.3$ & $1.66 \pm 3.33$ & - \\
\hline P.longifolia & $5 \%$ & 16 & $96.2 \pm 4.2$ & $3.71 \pm 4.29$ & - \\
\hline P.hysterophorus & $2.5 \%$ & 16 & $91.7 \pm 1.2$ & $8.29 \pm 1.23 *$ & - \\
\hline P.hysterophorus & $5 \%$ & 17 & $94.3 \pm 3.8$ & $5.67 \pm 3.84$ & - \\
\hline D.repens & $2.5 \%$ & 16 & $49.0 \pm 1.9$ & $50.96 \pm 1.92^{* * * *}$ & $222.2 \pm 14$ \\
\hline D.repens & $5 \%$ & 15 & $14.7 \pm 6.5$ & $85.08 \pm 6.35^{* * *}$ & $222.5 \pm 13.8$ \\
\hline
\end{tabular}

Note: Asterisk marks *,**, *** indicate significance of values as compared to control (water, inoculated) value at $\mathrm{P} \leq 0.05$ level according to

ANOVA, Tukey's post test.

Table 3. Effect of plant extracts on seed germination and seedling vigour

\begin{tabular}{|c|c|c|c|}
\hline Treatments & & $\begin{array}{l}\text { Vigor index (by shoot/ root } \\
\text { length method) }\end{array}$ & $\begin{array}{l}\text { Health index (by seedling weight } \\
\text { method) }\end{array}$ \\
\hline Water & & $830.2 \pm 62.3$ & $250.1 \pm 35.1$ \\
\hline Salicylic acid & $2 \mathrm{mM}$ & $701.1 \pm 52$ & $227.3 \pm 21.6$ \\
\hline D. repens & $2.5 \%$ & $902.2 \pm 105.2$ & $296.1 \pm 46.4$ \\
\hline
\end{tabular}


Table 4. Efficacy of seed treatments with solvent fractions of Duranta repens on induction of resistance against downy mildew of sorghum under the green house condition

\begin{tabular}{|lcccc|}
\hline Treatments & $\begin{array}{c}\text { Mean plants } \\
/ \operatorname{pot}( \pm 0.5)\end{array}$ & $\%$ disease & $\%$ Protection & $\begin{array}{c}\text { Mean dry } \\
\text { biomass } / \text { pot }(\mathrm{mg})\end{array}$ \\
\hline Water & 20 & $61.3 \pm 5.1$ & - & $464 \pm 33.7$ \\
\hline Salicylic acid 2 mM & 17 & $41.2 \pm 2.1$ & $32.7 \pm 3.5 * * *$ & $622 \pm 59.2$ \\
\hline Hexane fraction & 23 & $46.9 \pm 1.6$ & $25 \pm 5.5 * * *$ & - \\
\hline Chloroform fraction & 20 & $34.3 \pm 3.7$ & $43.8 \pm 6.1^{* * *}$ & $897 \pm 34$ \\
\hline Di-ethyl ether fraction & 20 & $49.6 \pm 5.4$ & $19 \pm 8.8 * *$ & $660 \pm 36$ \\
\hline Acetone fraction & 20 & $37.3 \pm 3.5$ & $39 \pm 5.8 * * *$ & $815 \pm 64.7$ \\
\hline Ethanol fraction & 22 & $39 \pm 2.6$ & $36.3 \pm 4.3 * * *$ & $881 \pm 69.8$ \\
\hline Water fraction & 21 & $54.8 \pm 0.7$ & $10.4 \pm 1.1$ & - \\
\hline
\end{tabular}

Note: Asterisk marks *, ${ }^{* *},{ }^{* * *}$ indicate significance of values as compared to control (water) value at $\mathrm{P} \leq 0.05$ level according to ANOVA, Tukey's post

\section{FIGURES}

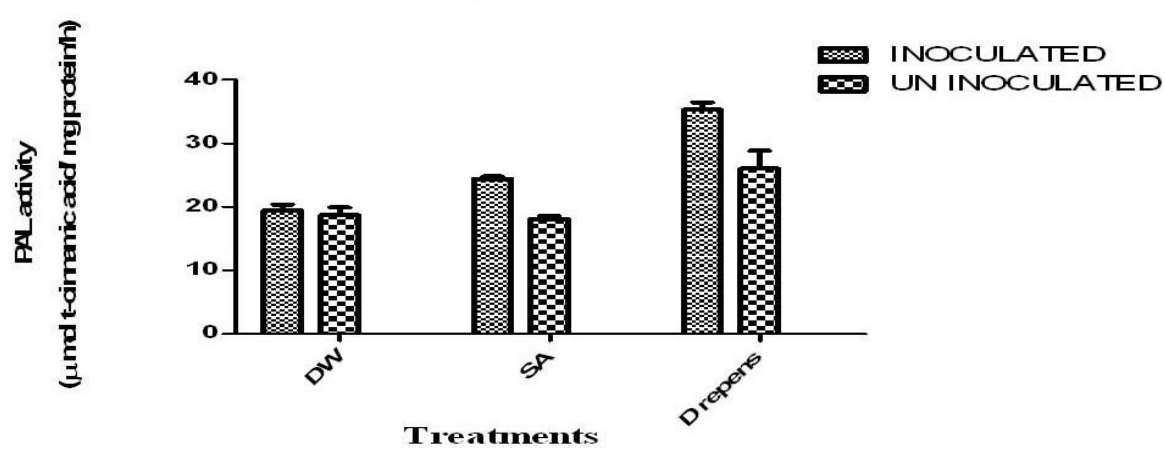

Figure 1. PAL Activity upon 3h seed treatment

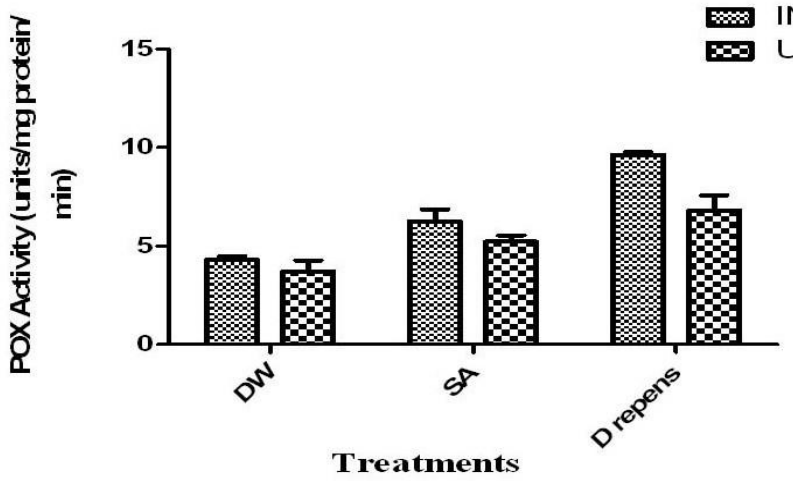

Figure 2. POX Activity upon $3 \mathrm{~h}$ seed treatment 